\title{
Study on the Influencing Factors of Urban Residents' Income in China
}

\author{
Guoran Zhang \\ School of mathematics and statistics, Central south university, Changsha 410083, China \\ 574621148@qq.com
}

\begin{abstract}
With the rapid development of China's economy, influencing factors of residents' income have become one of the research hotspots. This paper selects several factors that affect residents' income and uses the income data of urban and rural residents in China to conduct empirical analysis. It is found that firstly there is a positive linear correlation between economic development factors and the income of urban and rural residents. Secondly, there is a linear negative correlation between the economic environmental factors and the income of urban and rural residents. Thirdly, the institutional factors have a positive linear correlation with the income of urban and rural residents. Suggestions to improve the income of urban and rural residents: Encouraging and guiding entrepreneurship to promote regional economic development and to drive urban and rural residents to expand employment and increase income; Highlighting the focus of income doubling, striving to accelerate the pace of rural residents to increase income and narrowing the income gap between urban and rural areas; Narrowing the income gap, expanding middle-income groups and gradually building an olive-type society; Accelerating the transformation of economic growth mode, adjusting and optimizing industrial structure and industrial layout and developing circular economy and green economy; Improving the construction of the social security system and increasing the transfer income of urban and rural residents.
\end{abstract}

Keywords: income of urban and rural residents, principal component analysis, influencing factors.

\section{Introduction}

Since the reform and opening up in 1978, our country's economic has been rapidly taking off under the leadership of the Party. With China's existing resources and international communication, the living standards have been greatly improved, mainly reflected in the leap-forward growth of residents' disposable income. Although major achievements have been made, there are still many problems. As a matter of fact, China is still in the period of economic transition, the economic system is not sound enough, there is a certain gap between China and the developed countries, and the increase of residents ' income is still an important issue facing the Party and the country. Therefore, under the current background, the study on the influencing factors of China's residents ' income can not only consolidate the theoretical basis, but also make the country introduce corresponding policies to promote the growth of residents ' income, which is of great significance to China's economic development.

\section{Literature Review}

In recent years, the research on the issue of income equity tends to be refined and be carried out in a deep perspective. For example, the Simplified Endogenous Economic Growth Model (Mankiw, 2011) [1] shows that the social insurance and tax policies in government behaviors may lead to the difference of residents' income while bringing security and promoting economic development. In the process of urbanization, the difference of residents ' income usually depends on government behaviors (Guzhaolin, 2008) [2]. Studies from the perspective of social and economic environment have shown that major historical events such as economic depression and world war may lead to changes in the income level of residents. The accumulation of national wealth comes from resources rather than labor force, but resources are in the hands of a small number of people, which will also lead to widening income gap and uneven income distribution. In addition, direct income, individual differences, educational background, working and insurance status, geographical differences, and 
land ownership system may be important factors influencing the income level of residents. (China Income Distribution Research Center, Zhongnan University of Economics and Law, 2016) [3] In recent years, domestic research has found that the level of urbanization, the gap between rich and poor, social security expenditure and economic growth rate are all factors influencing the income level of urban and rural residents, among which factors such as urbanization process and industrial structure transformation may lead to a rapid decline in the proportion of residents' income. (Wang Chunyuan, Fang Qiyun, 2014) [4].

In addition, comparative analysis of domestic and foreign data shows that there are certain rules among the uneven income distribution, the large gap between urban and rural areas and the imbalance of regional development. And the sharp widening of the gap between urban and rural areas is the main reason for the widening trend in the distribution of Chinese residents' property.

Previous studies have explored the influence factors and measures of residents ' income level from various angles, and pointed out the influence of economic growth pattern, income distribution structure, government revenue and expenditure behavior left on the income level of residents. Based on the above-mentioned study results at home and abroad, this study attempts to expand the influencing factors of residents' income level to the variables of GDP per capita, registered unemployment rate, per capita consumption level, per capita wage and opening-up level. On the basis of China's provincial dynamic panel data, statistical methods are used to analyze the per capita disposable income of Chinese residents, and it is expected to provide a policy reference for raising the income level of residents.

\section{Composition of Income Distribution of Chinese Residents}

At present, the main income of urban residents of China is wages earning. Among the total income of urban residents, the proportion of each year's wages income is about $65 \%$. During the 12th FiveYear Plan period, the government introduced policies and measures to stabilize and promote employment, and the incomes of the residents grew steadily. And the wages income of urban residents increased by $53 \%$ from 2009 to 2013.

Table 1. Composition of China's urban residents' income sources from 2009 to 2013

\begin{tabular}{|c|c|c|c|c|c|c|c|c|c|}
\hline \multirow{2}{*}{ Year } & \multirow{2}{*}{ per capita total income(yuan) } & \multicolumn{2}{|c|}{ wages income } & \multicolumn{2}{c|}{ operational income } & \multicolumn{2}{c|}{ property income } & \multicolumn{2}{c|}{ transfer income } \\
\cline { 3 - 10 } & (yuan) & proportion & (yuan) & proportion & (yuan) & proportion & (yuan) & proportion \\
\hline 2009 & 18858.1 & 12382.1 & $65.6 \%$ & 1528.7 & $8.1 \%$ & 431.8 & $2.3 \%$ & 4515.5 & $23.9 \%$ \\
\hline 2010 & 21033.4 & 13707.7 & $65.2 \%$ & 1713.5 & $8.1 \%$ & 520.3 & $2.5 \%$ & 5091.9 & $24.2 \%$ \\
\hline 2011 & 23979.2 & 15411.9 & $64.3 \%$ & 2209.7 & $9.2 \%$ & 649.0 & $2.7 \%$ & 5708.6 & $23.8 \%$ \\
\hline 2012 & 26959.0 & 17335.6 & $64.3 \%$ & 2548.3 & $9.6 \%$ & 707.0 & $2.6 \%$ & 6368.1 & $23.6 \%$ \\
\hline 2013 & 29547.1 & 18929.8 & $64.1 \%$ & 2797.1 & $9.5 \%$ & 809.9 & $2.7 \%$ & 7010.3 & $23.7 \%$ \\
\hline
\end{tabular}

Data source: 2009-2014 China Statistical Yearbook

As shown in Table 2, the main sources of disposable income of rural residents in China are wage income and operating income. Among them, the proportion of wage income from net income increased from $40 \%$ to $45.3 \%$. With the gradual improvement of the rural social security system, the proportion of transfer income in the per capita net income of rural residents has increased from $7.7 \%$ to $8.8 \%$.

Table 2. Composition of China's rural residents' income sources from 2009 to 2013

\begin{tabular}{|c|c|c|c|c|c|c|c|c|c|}
\hline \multirow{2}{*}{ year } & \multirow{2}{*}{ per capita net income(yuan) } & \multicolumn{2}{|c|}{ wage income } & \multicolumn{2}{c|}{ operational income } & \multicolumn{2}{c|}{ property income } & \multicolumn{2}{c|}{ transfer income } \\
\cline { 3 - 10 } & & (yuan) & proportion & (yuan) & proportion & (yuan) & proportion & (yuan) & proportion \\
\hline 2009 & 5153.2 & 2061.3 & $40.0 \%$ & 2526.8 & $49 \%$ & 167.2 & $3.2 \%$ & 398.0 & $7.7 \%$ \\
\hline 2010 & 5919.0 & 2431.1 & $41.0 \%$ & 2832.8 & $47.9 \%$ & 202.3 & $3.4 \%$ & 452.9 & $7.7 \%$ \\
\hline 2011 & 6977.3 & 2963.4 & $42.5 \%$ & 3222.0 & $46.2 \%$ & 228.6 & $3.2 \%$ & 563.3 & $8.1 \%$ \\
\hline 2012 & 7916.6 & 3447.5 & $43.5 \%$ & 3533.4 & $44.6 \%$ & 249.1 & $3.1 \%$ & 686.7 & $8.7 \%$ \\
\hline 2013 & 8895.9 & 4025.4 & $45.3 \%$ & 3793.2 & $42.6 \%$ & 293.0 & $3.3 \%$ & 784.3 & $8.8 \%$ \\
\hline
\end{tabular}

Data source: 2009-2014 China Statistical Yearbook 


\section{Econometric Analysis}

GDP per capita: As a measure of economic development, GDP per capita is one of the most important macroeconomic indicators and a powerful tool to measure regional macroeconomic performance. As the per capita GDP increases year by year, economic development drives the growth of employment and income, and thus contributes to the increase of disposable income.

Registered unemployment rate: The unemployed have no source of income, and it leaves a strong negative impact on disposable income.

Per capita consumption level: Consumption level reflects the income level of residents.

Per capita salary of employed personnel in urban units: The salary that largely reflects the income of the residents plays a decisive role in the residents ' disposable income.

Opening-up Level: Foreign trade plays a very important role in the overall economy of the country, so it has a very strong impact on the income of residents.

Table 3. The Definition of Research Variables

\begin{tabular}{|c|c|c|c|}
\hline $\begin{array}{l}\text { Variable English } \\
\text { name }\end{array}$ & $\begin{array}{l}\text { Variable Chinese } \\
\text { name }\end{array}$ & Variable property & Variable meaning \\
\hline income & 居民可支配收入 & Dependent variable & $\begin{array}{l}\text { Annual average disposable income of urban and } \\
\text { rural residents in China }\end{array}$ \\
\hline Grow & $\begin{array}{c}\text { 国内生产总值增 } \\
\text { 长率 } \\
\end{array}$ & $\begin{array}{l}\text { Independent } \\
\text { variable }\end{array}$ & GDP growth in China \\
\hline Consume & 能源消耗 & $\begin{array}{l}\text { Independent } \\
\text { variable }\end{array}$ & Average energy consumption per 10000 -yuan GDP \\
\hline Labor productivity & 劳动生产率 & $\begin{array}{l}\text { Independent } \\
\text { variable }\end{array}$ & Labor productivity of all residents in China \\
\hline Social security & 社保情况 & $\begin{array}{l}\text { Independent } \\
\text { variable }\end{array}$ & $\begin{array}{l}\text { The proportion of social security expenditure in } \\
\text { total fiscal expenditure }\end{array}$ \\
\hline Urbanization & 城镇化率 & $\begin{array}{l}\text { Independent } \\
\text { variable }\end{array}$ & $\begin{array}{l}\text { Proportion of permanent urban population in the } \\
\text { total population }\end{array}$ \\
\hline Price index & $\begin{array}{l}\text { 居民消费价格指 } \\
\text { 数 }\end{array}$ & $\begin{array}{l}\text { Independent } \\
\text { variable }\end{array}$ & $\begin{array}{l}\text { Price movements of consumer goods and services } \\
\text { generally purchased by households }\end{array}$ \\
\hline Income ratio & 城乡收入比 & $\begin{array}{l}\text { Independent } \\
\text { variable }\end{array}$ & $\begin{array}{c}\text { Average income of urban residents divided by } \\
\text { average income of rural residents }\end{array}$ \\
\hline Engel & 恩格尔系数 & $\begin{array}{l}\text { Independent } \\
\text { variable }\end{array}$ & $\begin{array}{c}\text { Ratio of household food expenditure to total } \\
\text { expenditure }\end{array}$ \\
\hline Unemployment & 失业率 & $\begin{array}{l}\text { Independent } \\
\text { variable }\end{array}$ & Average unemployment rate of residents \\
\hline Outside & 对外开放程度 & $\begin{array}{l}\text { Independent } \\
\text { variable }\end{array}$ & Total import and export volume divided by GDP \\
\hline
\end{tabular}

\section{The Design and Analysis of Model}

In order to investigate the influence of various factors on the income growth of urban and rural residents in China, principal component regression was applied to find out the main factors and their impact on urban and rural residents ' income. PCR is a multiple statistical analysis that transforms multiple colinearity variables into a few independent comprehensive variables and then makes regression.

\subsection{Select Indicators}

Indicators such as GDP growth, average energy consumption per 10000 yuan GDP, overall labour productivity, the proportion that social security expenditure accounts for total fiscal expenditure., unemployment rate, urbanization rate, CPI, Income ratio, Engel, outside were involved into this study.

Establish a Regression Model of X and Y Variables 


$$
\begin{gathered}
Y=\beta_{0}+\sum_{i=1}^{10} \beta_{i} X_{i}+\varepsilon \\
\varepsilon \sim N(0, \sigma), \sigma>0
\end{gathered}
$$

$\mathrm{Y}$, the dependent variable, indicates the income of urban and rural residents, $X_{i}$, the independent variable, indicates the influencing factors affecting the income of urban and rural residents; $\beta$, the constant term, indicates the absolute of the income of urban and rural residents without any influence; $\beta_{i}$, the coefficient of regression of the independent variable $X_{i}$, indicates that the income of urban and rural residents will change by $\beta_{i}$ unit, if indicator $X_{i}$ changes one unit; $\varepsilon$, the random error term of regression result, obeys a normal distribution and is independent of each other, and the expected value of $\varepsilon$ equals 0 .

\subsection{Positive Analysis}

(1) Normalizing and standardizing the original sample matrix to eliminate the effects of different Orders of magnitude and dimensions. the original sample is processed with forward and standardized evidence. (The original data comes from the China Statistical Yearbook (2003-2014). the standardized data is $Z X_{\mathrm{i}}$.

(2) Check whether the data is suitable for Principal Component Analysis in accordance with the KMO test value and the significance Sig statistic. If the KMO is 229.375, which is relatively large in number, while the Sig statistic is less than 0.002 , which is highly significant. This indicates that the data applies Principal Component Analysis Method.

Table 4. Principal Component Analysis (1)

\begin{tabular}{|l|c|c|}
\hline \multicolumn{2}{|c|}{ Kaiser-Meyer-Olkin Measure of Sampling Adequacy. } & 0.882 \\
\hline \multirow{2}{*}{ Bartlett's Test of Sphericity Approx. } & Chi-Square & 229.375 \\
\cline { 2 - 3 } & df & 18 \\
\cline { 2 - 3 } & Sig. & .002 \\
\hline
\end{tabular}

Performing principal component analysis on each index by using SPSS 22.0 software to obtain the correlation matrix $\mathrm{R}$, then, calculating the eigenvalue, contribution rate and accumulative contribution rate of $\mathrm{R}$. The eigenvalues of the first three principal components (grow, consume, labour) are greater than 1 , and their cumulative contribution rate reach to $90.4 \%$, and the cumulative contribution of the principal component variance is greater than $85 \%$, indicating that the three principal components already contain the vast majority of information on all indicators and can be used for reducing dimension. Therefore, the first three principal components are selected as the evaluation indicators, in which the contribution rate of the first principal component F1 is $55.87 \%$, the second F2 is $18.63 \%$, and the third F3 is $15.90 \%$.

Table 5. Principal Component Analysis (2)

\begin{tabular}{|c|c|c|c|}
\hline \multirow{2}{*}{ Component } & \multicolumn{3}{|c|}{ Initial Eigenvalues } \\
\cline { 2 - 4 } & Total & \% of Variance & Cumulative \% \\
\hline Grow & 3.685 & 55.87 & 55.87 \\
\hline Consume & 1.229 & 18.63 & 74.50 \\
\hline Labour & 1.049 & 15.90 & 90.40 \\
\hline
\end{tabular}

\section{Conclusions and Policy Recommendations}

According to Analysis of experimental results, firstly, there is a positive linear correlation between economic development factors and the income of urban and rural residents. In other words, the economic development level, economic growth mode, labor productivity and the degree of opening up to the outside are positive in relation to the income of urban and rural residents. Therefore, there are effective ways to increase the income of urban and rural residents by accelerating the transformation of economic growth, maintaining a relatively fast pace of economic development, and 
increasing social labor productivity. Secondly, there is a linear negative correlation between the economic environmental factors and the income of urban and rural residents. Hence, in order to improve the income level of urban and rural residents, and really enhance the purchasing power of residents, the government should play a macro-control role to effectively control the price level and reduce Engel's coefficient. Thirdly, the institutional factors have a positive linear correlation with the income of urban and rural residents. Specifically, relevant institutional measures such as the government's social security system, employment promotion policies, and promotion of urbanization will help increase the income of urban and rural residents, especially for the moderate and low-income group.

\section{References}

[1]. N. Gregory Mankiw, Macroeconomics, 2011.

[2]. Gu Zhaolin, China's Urbanization: Pattern, Process, Mechanism, 2008.

[3]. China Income Distribution Research Center of Zhongnan University of Economics and Law, Survey Report on Income and Wealth of Chinese Residents, 2016.

[4]. Wang Chunyuan, Fang Qiyun, the Impact of Urbanization on the Income of Urban and Rural Residents, 2014. 